\title{
Sincere Hand and Faithful Eye. Cognitive Practices in Ensembles of Text and Drawing
}

Jens Loescher

\section{Summary}

With this paper I endeavour to adapt Lorraine Daston's term of cognitive practices in order to deal with material traces of writing and reading in natural philosophy of the seventeenth and the eighteenth century. In this paper I put particular emphasis on text-depiction-pairs. I hypothesize that basic cognitive faculties such as writing and reading serve as 'triggers' for cognitive practices of the scientific self: arts of memory, economies of attention, and the solidification and erosion of belief. For instance, the cognitive practices which are activated by 'reading' text-depiction-pairs are equivalent to the ones of the experimenter, who shifts his attention from observation to data to hypothesis and back. Building on Daston's well-known theory I focus on experimental cognition in specific epistemic situations.

Keywords: history of cognitive practices, text-depiction pairs, material traces, observation

\section{Introduction}

The topic of the present article is drawings (in letters and 'private' laboratory notebooks) and illustrations (in printed monographs) in the seventeenth and eighteenth centuries. These drawings and illustrations interrelated with the text function in order to evoke and enhance cognitive practices on the side of the writer and/or the reader. The term 'cognitive practices' has been coined

\footnotetext{
* I would like to thank Janet Vertesi, Lissa Roberts, and two anonymous reviewers for comments on an earlier draft of this paper.
}

PD Dr. Jens Loescher, Universität des Saarlandes, Fachrichtung 4.1. Germanistik, Postfach 15 11 50, D-66041 Saarbrücken (j.loescher@mx.uni-saarland.de). 
by Lorraine Daston and means "observation, economies of attention, arts of memory, and the solidification and erosion of belief". ${ }^{1}$ There are probably side branches to these cognitive practices such as the ability to build (and retrieve) analogies and associations, recursive 'processing' of research paths of one's own and of others, the ability to store experiments done, phenomena encountered (especially side-effects) and to retrieve these items from long term memory; finally, the selection of the phaenomenon crucis out of a vast amount of experimental data.

Previous papers on this topic have rested their argument on the assumption that the writer (someone who is performing the cognitive action of writing with all its automatized and 'higher' cognitive processes) uses strategies to alleviate cognitive loads. ${ }^{2}$ These strategies aim at the writer herself, but also at the reader who is struggling with the contents of the textual message. Writing seems to enhance (and is in turn fed by) at least three cognitive faculties: spatial knowledge, association, activation of episodic/ autobiographic memory. ${ }^{3}$ There might be a fourth component related to emotions.

My first working hypothesis is the assumption that the cognitive practices which belong to the scientific self and the cognitive practices which writing enhances are related to each other. That the natural philosopher or scientist is a writer (in the sense defined) is a fact which has not escaped the attention of historiographers of science since the first 'critical' editions of Newton and Boyle, later Galileo's were accomplished. Historiographers oriented towards the material - that is in opposition to Alexandre Koyre's 'idealism' - seem to always have had a clear notion of the way theories evolve a posteriori, after considerable work with paper and pencil has been done. But what exactly happens on the way to theory seems to have been black-boxed: one way to track the hidden material layers of the theory-laden episteme of the laboratory would be to scrutinise laboratory notebooks or other textual 'witnesses'. How did the writer use the space on paper in order to group problems, to transfer theorems by analogy, to switch from one topic or level of description to another, to arrange historical layers of theorizing on the subject or of his own mental moves? In short: how did the writer use writing in order to alleviate cognitive loads?

My second working hypothesis is this: if the writing natural philosopher employs techniques of 'paper work' on himself, why not on the reader? The means to do that would of necessity be textual//literary' strategies and/or

1 Daston 2004, 443-448, see 443.

2 Loescher 2009.

3 Fueller, Loescher, Indefrey 2013, 1-12. 
pictorial strategies. In this paper I concentrate on pictorial strategies of illustrations and drawings which aim at the reader. By 'reading' the pictures she is forced into the cognitive practices of the scientific self. She is observing, she allocates her resources of attention, she memorizes items, she functions as 'virtual witness', she associates and draws analogies.

'Progressing' from the seventeenth to the eighteenth century, from Hooke, Boyle and Leeuwenhoek to 's Gravesande, Desaguliers, Nollet, Sigaud de Lafond, the one major difference in applying textual/pictorial strategies is the recipient. In the seventeenth century the recipient is the colleague, the savant. This means that private communication in letters on the one hand and printed volumes offered to the public on the other hand hardly differ. The impression looking at Swammerdam's manuscript bundles of the Biblia Naturae-corpus is that of a finished opus. Swammerdam makes sure that the necessary drawings/copperplates are attached to his letters to Thevenot just the way Leeuwenhoek does it with his missives meant for publication. Consequently, Swammerdam's late editor, Hermann Boerhaave, had the majority of the Biblia Naturae-manuscripts printed without alterations, Oldenburg sent Leeuwenhoek's letters directly to the printer.

In the eighteenth century the missive is transformed into the text book. Scientific innovation is marketed. Science is popularized; the secluded realm of the laboratory becomes a public space. The shadow bending over the microscope in the early morning hours is replaced by a public demonstration experiment: experimental cognition is turned into distributed cognition. In order to make this audience adhere to cognitive practices of the scientific self, additional 'triggers' need to be implemented in the pictorial design of the textbooks. The paltry laboratory is refashioned into the opulent salon, welldressed agents showcase the instruments and perform in the experimental setting, demonstration instruments and experiments are depicted as theatre performances.

The function of illustrations is completely altered: in the seventeenth century they serve to communicate pieces of experimental design which are too difficult to grasp in textual description (for writer and reader alike). In the eighteenth century the pictorial strategies evoking cognitive practices serve commercial interests and therefore aim at flattering the noble customer. It is, cum grano salis, the time of spectacle: of manuals and kits, of 'Do it yourself-Science'. The scientific self who was addressed by the pictorial strategies in the seventeenth century has now turned into the economical or layman-self who wants to be entertained. That is why the demonstration experiment by the impresario cannot be distinguished from 'serious' experimental conduct in the eighteenth century. 


\section{Experimental Cognition}

In every discipline there are tides of 'in'- and 'out'-methodologies. The internalist/externalist debate in the field of the history of science has had a clear winner. Lorraine Daston's coining of the term cognition in the sense of (habitual) practices therefore is clearly distinct from what Frederic Lawrence Holmes meant by it: inventive (and investigative) pathways of an individual scientist struggling for knowledge and invention. As a writing researcher and philologist I do not mean to interfere with this battle in the field. One way of doing this was executed by Nancy Nersessian in the late eighties and nineties launching the project of a "cognitive history of science". ${ }^{4}$ Hiring cognitive science and the history of science is an endeavour which will most probably result in shipwreck. There are too many nations on board. I therefore make no claim in this kind of 'cognitive historio-graphy'.

On the other hand there is a long history of culture and cognition merging into quite productive research patterns. Wilhelm Wundt, Lev Wygotski, Michael Tomasello are godfathers who come to mind first. Tomasello's well known statement: "I do not know if this project belongs to science or humanities" 5 in the German edition of The cultural origins of human cognition is a hallmark for researchers who do not wish to be exclusively 'hard-' or 'soft-science'. Besides, regarding the confined object and objective of this paper I do not see major differences between Daston's and Holmes's understanding of "cognition'. Holmes - "narrowly internalistic" 6 as he once ironically labelled himself - utilizes terms like 'creativity' and 'mental field' with astonishing matter of course. He repeatedly refers to Howard Gruber, a trained psychologist who ventured in the field of scientific creativity.

Daston is one of the main protagonists of the 'culture-paradigm', but she has repeatedly criticised overt sceptical, 'anti-essentialistic' approaches from Feyerabend to Latour, thus implicitly granting a certain kind of interplay of the scientist's personality (and mind) on the one hand and the cultural frame on the other. Clearly, Daston's (and others') history of reading practices cannot (and does not wish to) do without some hypotheses about what might have happened or what happens inside the head of the reader.

We build - respectfully - on Daston's work on cognitive practices, but we wish to shift the focus from her a priori perspective of the epistemic relation

4 Nersessian 1988; Nersessian 1995, 194-211, see 197. See also Carlson/Gorman 1990; Carlson/ Gorman, 1992; Tweeny/Gooding 1991.

5 «Ob das eine naturwissenschaftliche oder eine geisteswissenschaftliche Untersuchung ist, weiß ich nicht». Tomasello 2000, 9.

6 Holmes 1990, 349-366, see 363. 
between the scientific object and the observing scientist ${ }^{7}$ to specific, ad hoc, 'productive' experimental situations. Cognitive practices are not the exclusive domain of a supra-individual, 'transsituational' scientific self, but also influence singular, 'unique' encounters between object and observer. They are processed 'from scratch' (combined, transformed, hierarchized) based on environmental, material, and experimental constraints. Production of knowledge and innovation in literature and science are basically due to this ad hoc function. ${ }^{8}$

In the field of history of science, cognitive approaches are still regarded as 'a-historical', that is: not interested in the historical signature of discourses, narratives, materials, and objects. To our view, this Manichean 'Us here - them there' is not viable. Since cognitive practices evolve, gain dominance and perish due to a nonlinear transformation of collective thinking styles and ethical habitus they need to be described on their specific historical level. It is important to keep in mind, though, that collectivist and constructivist accounts of cognitive practices have no terminological armature for the description of specific experimental situations like the observer looking through a microscope. At first, there is a common sense relation of observer to object which is familiar: instrument, dissected specimen. As soon as the instrument is 'turned on' the object, the common sense event is switched into a singular one: the experimental situation. The observer is learning to see through the microscope and establishes ad-hoc relations to the object. These intermittent epistemic relations with a specific temporal and also spatial signature are due to cognitive processing during the experimental situation. This kind of cognitive processing during the singular event of the experimental situation is not fed by collective thinking styles, habits, pragmatic frames or tacit knowledge. There is a historical imprint on this kind of practice, but no 'a priori'-thinking style framing it.

There have been three influential theories on cognition in science so far: one is the mentioned Neo-Kantian approach. The second line of argument rests on the various versions of distributed cognition, ranging from Ludvik Fleck to Edwin Hutchins' 'Cognition in the Wild'. ${ }^{9}$ Third, there is Ian Hacking's experimental cognition, ${ }^{10}$ which has often been labeled 'realist' in

7 Daston/Galison 2007. Especially chapter four, where Daston and Galison speak of 'personae' of natural philosophers/scientists in a typological way. Cognitive practices in this view derived from epistemic virtues in the Kantian sense. Daston has been much more 'psychological' with regard to cognitive practices in Daston 2008, 97-110. See also Daston 1995,2-24; Daston 1984, $717-721$.

8 Some historians of science did conquer the "murky realms" of creativity - an ironical coining of Daston's (Daston 2008, 101): Roberts/Schaffer/Dear 2007; Gruber 1981, 41-59.

9 Fleck 1980, 1983, 2011. Hutchins 1995.

10 Hacking 1983, 1984, 1985. 
contrast to readings of Fleck as 'constructivist' ${ }^{11}$ What we would like to put forward is a brand of experimental cognition.

According to Stanislas Dehaene's recycling hypothesis, writing is a function of a closed cultural system which 'piggybacks' on older neuronal/cognitive circuits of visual/spatial construction and language comprehension. ${ }^{12}$ Building on this, we hypothesize that cognitive practices and the function of writing interact, especially with regard to spatial and (working) memory effects ${ }^{13}$. More specifically, the argument of this paper rests on the assumption that cognitive practices can be triggered by writing and, possibly, reading. I will not elaborate on this in terms of empirical writing research here, but keep to a strict material - and that is: historical - level of description. If the hypothesis is correct then one would expect certain writing traces on the script carriers and, possibly, in text books. One would be able to watch epistemic paths unfold during the documented process of writing (or reading).

\section{Seventeenth Century. Missives of the Savant}

\subsection{Miniature and 'Automatic' Writing (Robert Hooke, Antoni van Leeuwenhoek)}

In the first chapter of Robert Hooke's Micrographia (1665) ${ }^{14}$ "Of the Point of a Sharp Small Needle" the author imagines an amazing 'scene of writing': the 'dot' of a printed full stop letter magnified through the microscope; Hooke claims that this letter print has been taken by chance from a volume. The first of a famous sequence of depictions of all kinds of natural objects - heads of the fly, seaweed, fish scales, hair, feathers, 'teeth' of snails, eggs of silkworms, urine scale, charcoal, glasdrops und body pores - is in fact an example of the outcome of a cognitive practice of science: the written and printed text. A very tiny item marked with 'A' serves as tertium comparationis for the magnifying powers of the microscope. Being objected to this instrument the dot appears as a "great splatch of London dirt". ${ }^{15}$

11 Both labels have serious shortcomings in our opinion.

12 Dehaene/Cohen/Sigman/Vinckier 2005, 335-341.

13 Some historians of science have dealt with writing as a cognitive function. See Dennis 1989, 309-364. Of course Hans-Jörg Rheinberger and his former research group 'Knowledge in the making' have been pioneers in the field. See Rheinberger 1992, 2001; Krauthausen/Nasim 2010; Hoffmann 2006.

14 Hooke 1665 (in the following: Micrographia). Observation 1: "Of the Point of a Sharp Small Needle."

15 Hooke, Micrographia, op. cit., 3. 


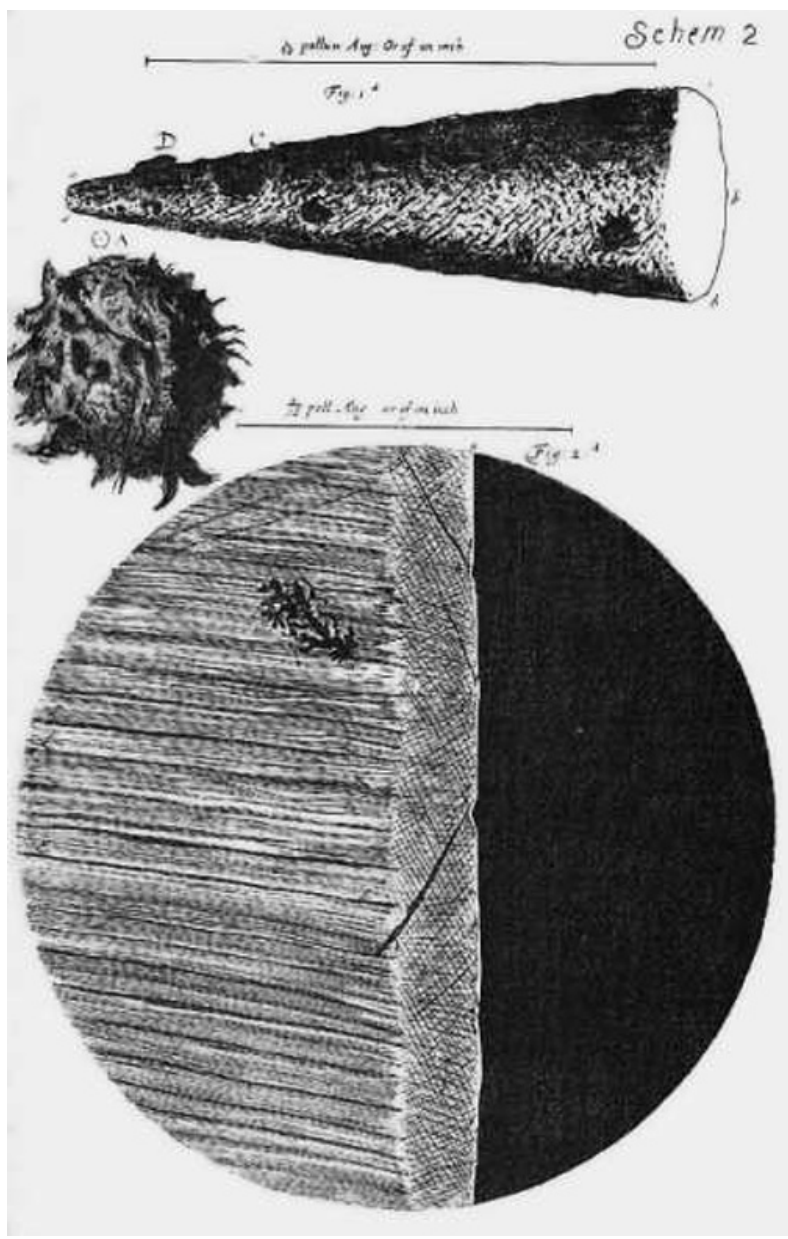

Fig. 1: Robert Hooke: Micrographia, Pl. 1 (facing page 3).

The close resemblance of this key item of microscopic inquiry with the title Micrographia and thus with a cognitive practice of science is evident. This resemblance is stressed in the following paragraph - one of many of Hooke's digressions. It is a memory of a writer who managed to spell out "the Lord's prayer, the Apostles creed, the ten commandments, and about half a dozen verses besides of the Bible" 16 on a two-pence-coin. This miniature-writing is a trigger for enthusiastic imagery of the author. It would, for example, be extremely useful for a "secret Intelligence without any danger of Discovery or mistrusting". ${ }^{17}$ The "solidification and erosion of belief", which Lorraine Daston suggests as a foundation rock of cognitive practices, seems to be represented in this kind of miniature writing of the microscope. The philosophical instrument is writing down the secrets of nature. Since there is no agent interfering with this the outcome of this inscription of the images,

16 Hooke, Micrographia, op. cit., 3.

17 Hooke, Micrographia, op. cit., 3. In passing, the handwriting on some pages of the Hookefolio is indeed miniature, not more than $6-8 \mathrm{~mm}$ size-letters, barely legible with the naked eye. 
which the microscope produces, is completely trustworthy. The reader is the recipient of the secret messages of the knowledge of nature and the miniature-writing is the code which must be deciphered by him.

It has been pointed out correctly that the difference between dioptrique instruments like microscope and telescope on the one side and the air pump on the other rests on the fact that the experience of the observer could not be transformed into a public experiment. ${ }^{18}$ There was no way of witnessing what the researcher saw in the microscope with a given object at a certain time. That is what sparked arguments from Galileo onwards as to what actually was to be seen in the 'pictures' the telescope 'produced' or if it was a better idea to dispose of these instruments altogether and trust the naked eye as Hevelius proposed. Hooke's strategy throughout the Micrographia is directed at the 'objectivation' of the personal experience into reliable data of the experiment. What he actually postulated was an automatized circuit of higher and lower cognitive faculties resulting in a drawing which resembled the objective 'picture' produced by the lense(s) of the microscope. The "sincere hand and the faithful eye" ${ }^{1}$ are just two components of this circuit:

Beginning with the hand and the Eyes, and to proceed on through the Memory, to be continued by the Reason, nor is it to stop there, but to come about to the Hand and Eyes again, and so by a continual passage round from one faculty to another, it is to be maintained in life and strength. ${ }^{20}$

This automatized circuit guarantees that the drawing the observer produces in fact constitutes the epistemic object. Instead of Gentlemen witnesses there is a textual witness bearing the experimental object. A cognitive interplay of hand, eye and memory/reason produces this paper witness. The basic strategy is to keep the 'production line' short: observer, drawing/draughtsman, engraver of the copper plate. There is at least one incidence when Leeuwenhoek utilizes the impartial hand of the draughtsman in order to ensure 'objectivity'. ${ }^{21}$

\subsection{Paper Tools (Robert Boyle)}

If the 'micrographia' are to be deciphered there has to be a code of cognitive conduct. The text needs to establish a cognitive frame on which the reader can rely. One of these elements of cognitive framing are letters in the illustrations which mark parts of the instrument or object that is depicted. These alphabetical characters in the illustration I term paper tools borrowing

18 Dennis 1989, 309-364. see 319.

19 Hooke, Micrographia, op. cit., IV-V.

20 Hooke, Micrographia, op. cit., VII.

21 See Loescher 2014. 
from Ursula Klein's articles on that matter. ${ }^{22}$ Paper tools are, in Ursula Klein's finding, visual, iconic, manoeuvrable 'signs' (letters, pictures, abbreviations) which condense meaning and perform syntactical transformations. In this context paper tools 'import' the illustration in the text: "A is a siphon which ..." On the other hand, paper tools import language into the illustration (the letters). They transport a host of meanings and side-meanings of complex entities - be they chemical substances as with Berzelius' 'short-hand-formulas' or parts of instruments or natural objects in the cases in question here.

In Boyle's famous depiction of the air pump there is a multitude of paper tools guiding the way the recipient is supposed to read it. ${ }^{23}$ The cabinet of instruments and 'sub-instruments' being cramped on one page is not only a matter of high costs of producing copper plates. In the eighteenth century, this technique of dense representation is still common. It is also an effort to give an encyclopaedic view of the 'instrument-family' in question. To order the mass of illustrations paper tools on several levels need to be implemented.

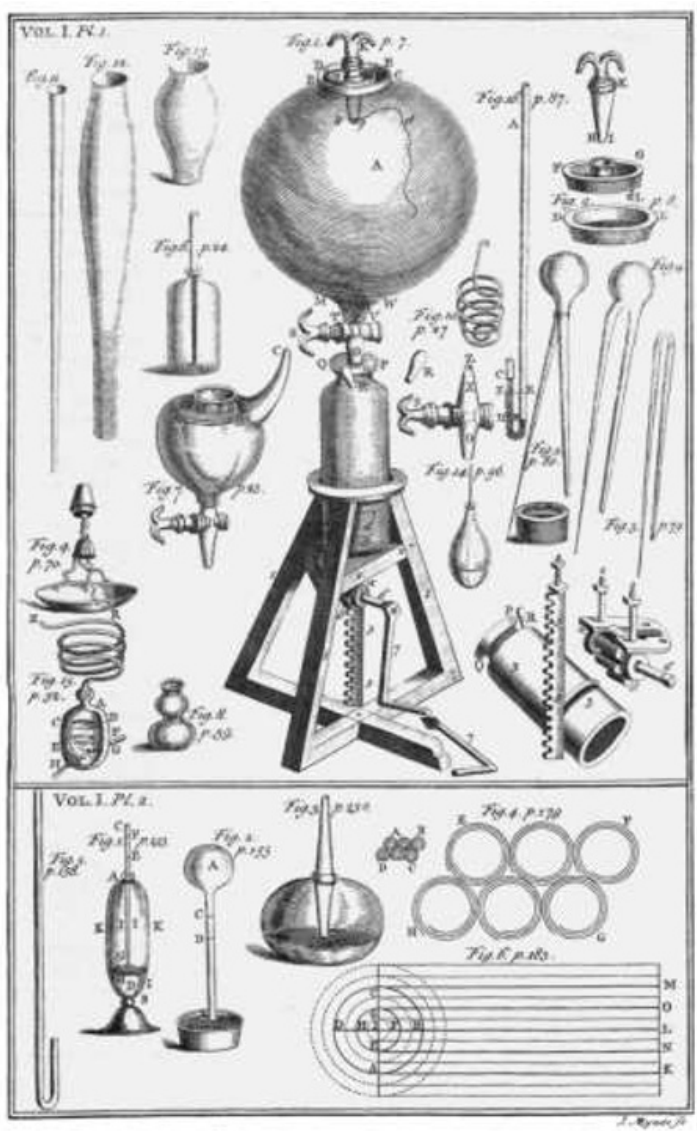

The table number, the ordering of the single illustrations and finally the markers 'inside' the illustrations (letters) serve as a cognitive frame, a ' $\mathrm{hi}$ erarchy' of the 'levels' of the instruments displayed. Paper tools, shifting from instrument description to instrument depiction and backwards, serve as a way to combine reading strategies of pictures and of text. Thus they frame the cognitive effort the reader takes in order to understand the function of the scientific apparatus or the micrographia of the natural object.

Fig. 2: Robert Boyle: New Experiments touching the spring of the air, in: The Works, p. 250.

22 Klein 2001, 265-302.

23 My discussion of scientific instruments in the course of this paper is indebted to: van Helden 1983, 49-84; van Helden/Hankins 1994; Warner 1990, 83-93; Bennett 2003, 129-150; Taub 2009, 337-343. 
The "shuttling back and forth between text and image" 24 is a tiring enterprise compared to letters where the drawing is placed conveniently close to the textual description. With printed volumes, especially ones with copper plates, the reader is forced to memorize the description when 'scanning' the book for the illustration and to memorize the components of the illustration when leafing back to the text. The first working hypothesis is that paper tools support this act of memorization, be it of lingual or pictorial elements. The second hypothesis would be that this reading strategy resembles a crucial activity of the experimenter: when looking for the phenomenon crucis in the vast material of data collected, the experimenter is building tentative frames of semantic hierarchy of the data, she puzzles the bits and pieces to larger coherent entities which again are arranged in situative, narrational, or 'logical' sequences. Shuttling back and forth from hypothesis to instrument to data the researcher is trying to make sense of a seemingly senseless pattern.

Paper tools seem to play a crucial part in this as they symbolize larger semantic units of the data. This is what Ursula Klein has pointed to with respect to Berzelius's formulas. Of course standardized drawings or icons or abbreviations could fulfil this function: Galileo did not write 'triangle', but used the icon in the Codex. The point is that the reader's activity in trying to make sense of an utterly new and challenging matter by gradually forming a mental map with the help of paper tools is quite analogous to that of the scientist just described. Paper tools are the manoeuvrable semantic-laden entities which prevent the shuttling reader/scientist from forgetting what she was up to.

\subsection{The Shuttling Observer (Antoni van Leeuwenhoek)}

The first one who used the Tubulus vitreus is a Dutchman, living at Delft, named Leeuwenhoek, but all he could do with the microscopes concerns only externa, or things he puts in his glass tubes. It is impossible to go into discussion with him, as he is biased, and reasons in a very barbarical way, having no academic education.

(Jan Swammerdam, Letter to Thevenot)

Perusing the voluminous letters Leeuwenhoek sent to Oldenburg, it becomes clear that there is practically no limit to his interests. The way he changes matters in his missives or rather: the way matters change is nauseating. There is a constant switch of subject in the experiment (the louse, then the leaf it is sitting on, then the water drop, and so on) and there is a perpetual reporting voice never silent, when Leeuwenhoek describes and interprets his data. That is why Leeuwenhoek who had a draughtsman produce his images is in fact a better example for the textual/pictorial strategies in question here than Swammerdam and the other microscopists of the seventeenth century.

24 Daston 2004, 444.

Gesnerus 71 (2014) 
In his second letter to Oldenburg, the 15th of August 1673, Leeuwenhoek turns to one of his favorite instruments, the tubulus vitreus. These glass tubes are still in use in microbiological laboratories today, of course considerably refined. The basic idea is that one can easily vary air pressure, the density of the liquid, and one can isolate very small portions of it if the glass tube is considerably thin. Leeuwenhoek set his glass tubes in front of the lense instead of a specimen in order to do research on blood, milk and a lot of other liquid substances:

I cannot forbear to give you my thoughts concerning the Compression of the Air. I take a narrow glass-pipe, as (in Fig. 1) AB, hermetically sealed above in A; which pipe I fill about half full of water, as EB: Into it I insert the forcer DC, which is a wire, wound about at D with a piece of leather fitted into the glass-pipe, but first thrust into hot Candle-grease, that so neither Water nor gross air may pass through it. The water which in EC, is by the forcer DC forced up, whereby the Air, that is between A and E, is compressed into a hundred times less room than it hath before this pressure. And, forasmuch as 'tis certain to me, that no Body can be brought into less Dimensions than it is, except some other body be at the same time dislodged out of it [...], the Air therefore cannot be compressed together, and be made a hundred times less [...]. I cause it (components of the air, JL) to be dislodged by the forcible pressure to be dislodged and to pass through the Glass. This pressure is greater than many imagine..$^{25}$

These things thus supposed, being desirous to try whether any particles of the second stuff, or other parts somewhat bigger than the smallest stuff, could be pressed or forced through the Glass, I prepared for that purpose another Glass-Pipe as Fig. 2 and took a third one half its length, and so much wider, as to shoot over the second, as here GM: Which wider pipe I joined to $\mathrm{G}$ by means of the fire, leaving it open at the end $\mathrm{M}$ with a hole as small as a hair, imagining that if by the Forcer KH I should force up towards L the Water that is between I and N, that then the particles driven out of the inner-Glass, and being bigger than those which by the continual ethereal motion pass through it, and passing into the exterior Glass, would there require more space, and consequently drive out some Air at the little hole in the exterior pipe at M: And to see the event hereof, I did put in the outermost part of the small hole $\mathrm{M}$ a little water, which filled the hole only in the foremost part of it, thinking, that as I should drive the Air out of the innermost Glass, the same passing into the exterior Glass, would thrust the water out of the little hole. But what motion soever I make with the Forcer $\mathrm{KH}$, and press out the Air NL, the water at the small hole M keeps its station; and yet, if I do but apply my warm hand to the exterior pipe MG, the water at M presently flies out. This puzzles me, nor can I find a satisfactory reason for this Phaenomenon. ${ }^{26}$

25 I follow the excellent longue-durée-project of the edition of Leeuwenhoek's letters by a Dutch committee with changing members over the years: "The Collected Letters of Antoni van Leeuwenhoek", Amsterdam, Swets\&Zeitlinger, 1939. The first three volumes used the historical English translation of the Philosophical Transactions, from volume 4 onwards the editors supplied a modern English version of Leeuwenhoek's "low Dutch" (Oldenburg). In the following: Letters. Letters, op. cit., vol.1, 57-58.

26 Letters, op. cit., vol.1, 59-61. 


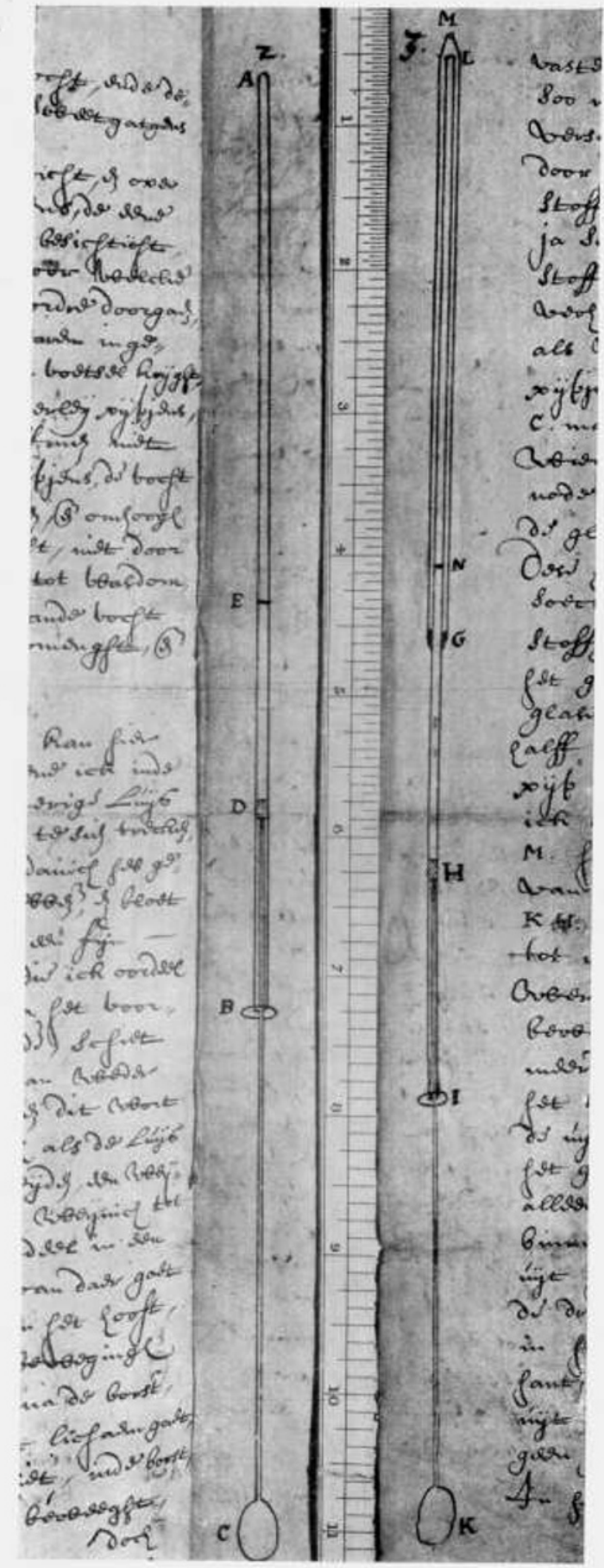

Plaat V.

Table V.

Fig. III. Glazen buisjes tot onderzoek van den luchtdruk. Inktteekeningen van LEEUWENHOECK.

in de kantlijn van den brief van 15 Aug. 1673 (Brief 2, blz. 56-58).

Fig. III. Glass-tubes for examining air-pressure.

Drawings in ink by LexuwenhoEcK,

in the margin of the letter of Aug. 15th 1673 (Letter 2, p. 57-59).

Fig. 3: Antoni van Leeuwenhoek: Letters. Vol. 1, p. 37.

As is obvious in the digitized image, Leeuwenhoek drew sketches of the instruments with the least possible distance to their description in the text. Deictic remnants ("here in Figure 3"), but also paper tools tie text and drawing together. On the right page paper tools can be discerned in the middle 
section: $\mathrm{M}$, the forcer $\mathrm{KH}$. Also, the latter seems to have been corrected, strengthening the hypothesis that the text was produced first. In the letter of 1 st of June 1674 arrows point to the drawing. Theoretically, the writer/drawer could dispose of paper tools altogether and settle with positing arrows. But doing this would mean to forsake the productive mode of switching cognitive realms: from drawing to text and backwards. In principle, the hiatus between the two techniques of communicating science is not bridged, but explicitly maintained.

This is probably not due to the need of having a second leverage for argumentation - "aliquid in pictura(e)" as Janet Vertesi has put it ${ }^{27}$ - , but due to the need of having two cognitive spaces the writing or reading agent utilizes in order to produce new epistemic pathways or objects. Lorraine Daston, Schaffer and Shapin and others have argued that these ensembles might parallel the temporary cognitive 'profile' of the performing or witnessing experimenter. Indeed, as Hooke describes in Micrographia, it is necessary to draw the sketch of the object observed in the microscope while watching it. Hooke then supplies the reader with a prolix description of the method of keeping the sheet of paper close to the microscope and dedicating just one eye to the sketch while the other rests on the magnified object.

I quote John Theophile Desaguliers with a similar record:

To know how much any of these single Microscopes magnify [...], take a round piece of Paper of about two to three Inches Diameter, and dye it black with Ink, then paste it on a Pane of Glas in the Window and recede so far from it, till looking thro' the Microscope with one eye on the Object, and with the other on the Paper, you perceive them both of the same bigness, or the one exactly to cover the other, the Proportion between the Paper and the Object will be exactly as the Distance of the Object from the Microscope to that of the Eye from the paper; and consequently when the Object appears of the same bigness with the paper, it is magnified in that Proportion. ${ }^{28}$

Slightly exaggerating, I suggest that the reader is supposed to look at the drawing with one eye and to read the text with the other. That would be the proper way of observing by continuous shifts of attention. The basic idea is that Swammerdam and Leeuwenhoek do not need to implement drawings in every instance. It is, rather, that by doing this they simulate the experimental situation and the need to constantly shift attention: a competence necessary for the novice reader.

Reading Leeuwenhoek's text close reveals that it is only a small part of the experiment he actually performs. The bulk of it is in fact a thought exper-

27 See the excellent article of Janet Vertesi. Vertesi 2010, 209-243, esp. 241.

28 John Théophile Desaguliers: Cours de physique expérimentale, traduit de 'Ànglois, par le R.P. Pezenas de la Compagnie de Jesus, Professeur Royal d' Hydrographie à Marseille. Enrichi de Figures. Tome premier. A Paris, chez Jacques Rollin, 1751. In the following: Cours. Citation Tome I, 175 . 
iment: denoted by abounding verba cogitandi. Before the experimenter 'sees the event thereof' and 'does' perform part of the experiment - without success - , he is "imagining". The narrative is focused on the experimenter in the 'real' experiments as well: he "thinks" or "is puzzled".

Especially in thought-experiments drawing is a productive tool. It seems to assist the writing/drawing agent in checking the plausibility of the experiment. But, is it not that drawings destroy the eidetic marvelousness of the thought experiment, which avoids "the chaotic world of inchoate experience" ${ }^{29}$ Do they not put the dirt back in the golden dish again? If thought experiments are the transformational grammar of real experiments, fed by an innate mechanism of reasoning and sedimented experience, then illustrations interfere with this frictionless genesis of phenomena out of transformation rules. At least that is the Wittgensteinian scepsis most advocates of thought experiments adhere to. Thought experiments ought to have a life of their own and the embodied visualizations do not resemble illustrations, as Gooding has suggested.

But, apparently, that is precisely what Leeuwenhoek is doing. He uses the drawing in order to perform a thought experiment. As a 'material' writing researcher I am prone to ask if the mindful hand drawing a picture is not 'generative' in the sense of thought experiments. There is the same kind of transformational grammar involved: drawings adhere to rules of reason and experience, albeit not carrying the full 'weight' of real objects and obstacles, but in a secluded realm where all sorts of combinations and 'compositions' might emerge - as long as the 'generative' rules are applied. With Leeuwenhoek, the interplay of concrete drawing and 'messy' verbalization (mixing stream of consciousness of the experimenter and 'proper' description) seems to initiate a productive sort of thought experimentation.

\subsection{Memoranda (Leeuwenhoek, Flamsteed)}

What seems to be evident with Galileo's ensembles or "memoranda" (Stillman Drake $\mathrm{e}^{30}$ ), meaning combinations and local arrangements of calculation, data-tables, text and drawing on a single sheet of paper ${ }^{31}$, is the mnemonic impact which enabled the author to keep the 'logical' or inventive/productive chain of 'propositions', mathematical or physical entities in flux. The most obvious reason for this is the space on script carriers which can be filled

29 Gooding 1992, 280-290, 282.

30 Drake 1978, 80.

31 Samples for memoranda are fol. 61 recto, fol. 64 recto, fol. 82 recto, fol. 84 recto, fol. 96 verso, fol. 139 recto, fol.147 recto, fol. 160 recto. In: Galileo Galilei: "Notes on Motion" (Online Resource Max Planck Institute for the History of Science). 
with elements as for example text blocks in a manner free from restrictions of regularity and symmetry. Looking at material of the sixteenth century the - nota bene - cultural rules for filling the space of the script carrier seem to not have been as strict as in later times. This enabled writers to follow strategies of alleviating cognitive loads by placing items on the sheet of paper in certain local correlations. Moreover, these memoranda serve as mental representations of writing scenes in the past and evoke the full set of ideational strata that were present at that time. Writing seems to enhance this kind of encoding and retrieval of episodic memory. The mnemonic function of writing is crucial with writers who ponder about long term projects, in the case of Galileo's Discorsi a time span of thirty-eight years.

Frederic Lawrence Holmes's diligent studies of laboratory notebooks in later stages of scientific progress make it overtly clear that ensembles of sketches and text are productive for the scientist working or reworking the bench. ${ }^{32}$.

1676, Dec 19 hour, h I II

m 80900 the morning the suns following limbe was in the same Azimuth with Eltham Steeple.

His true Azimuth from the Meridian at this time by calculation found $51^{\circ} 15^{\prime}$ East $=$ to the Angle EOM.

The Angle subtended betwixt Eltham Steeple and the Windmill at Bromley. at the observatory on Saturday last $48^{\circ} 15 \% / 4=\mathrm{EOB}$

Therefore the Azimuth of Bromley Windmill B from the meridian Eastwards BOM $3^{\circ} 00^{\prime}$.

But the Azimuth of Bromley Windmill from the Magneticall Meridian taken yesterday was one degree or at most $1 \frac{1}{4}$ gr.[ade] to the west $=$ wards $=$ BOM.

Therefore the variation Mom $4^{\circ} 00^{\prime}$ or at most $4 \frac{1}{4}$ degrees. Westerly in the North. to the East in the South partte of the compasses. By the equilibrated needle one foot long

February 25 1679/80 in the Observatory at Greenwich: by I.Flamsteed:

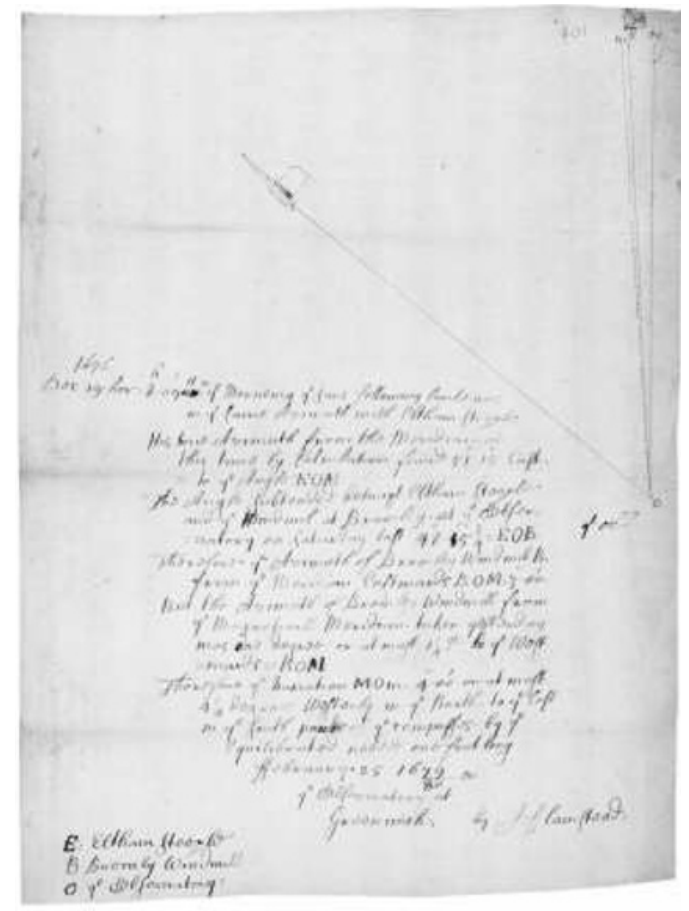

E: Eltham Steeple

B: Bromly Windmill

O: the Observatory:

Fig. 4: John Flamsteed in: Hooke-folio, $401 .^{33}$ Transcription by Jens Loescher

32 Holmes 1981, 1985, 1987, 1991.

33 I chose to transcribe the page myself, but, of course, gratefully consulted the readings of Lisa Jardine's team. 
By 'changing' the representation of epistemic objects (drawing, text, calculation, data table), by switching the mode of cognitive processing or reprocessing of these objects and, finally, by the mnemonic 'architecture' of the resulting ensembles there are epistemic pathways opening up to the writing, working, reworking scientist.

Flamsteed is measuring the Azimuth, meaning from his standpoint (the observatory) he aims at a fixed 'point of interest', Eltham Steeple, and then takes the projection of the vertical circle of the polar star on the horizon as second mark: this is the Bromly windmill or two points close to it: $\mathrm{M}$ and $\mathrm{m}$. First of all, this small sheet of paper apparently bears data and calculations covering three years. It must have been kept for further usage for that period of time. The drawing depicts the three points and the changing Azimuth angle. The legend on the bottom of the page seems to have been appended later. Drawing and text are interrelated in a multitude of ways: by paper tools, by names, by drawings in the drawing (the sketches of the houses). Drawing and text are not separated to different realms on the paper, but they 'merge'.

It is not just that the sides of the triangle 'cut' into the text, but that the text is arranged in a manner that seems to relate to the drawing. The first two lines had to be bent slightly in order to not interfere with the drawing, exemplifying that the latter probably was done first. ${ }^{34}$ The text is structured in logical steps which are demarcated by shifting margins on the left side. The last segment 'thins out' on the left and right sides, which is common for autographs of that time. In this case, nonetheless, it seems as if the arranged text resembles the tapering shape of the triangle. The drawing bears little symbols of the places which have an interesting effect of alleviating the 'reprocessing' of the experimental setting by the reader: recall the paper tools mentioned before.

What functions does this kind of ensemble have? Among others these are: 1. Alleviation of cognitive loads (for writer and reader) by establishing distinct spaces of cognitive modes on the script carrier.

2. Initiating memory encoding and retrieval.

In short, the functions are spaces and traces. With Flamsteed, there are two separate cognitive realms on the paper which enable the writer and reader to change the mode in which they are looking at the problem. The reason why the drawing is so prominent here is that it is indispensable for communicating the problem. The writer who rereads the memorandum and the reader shift their attention from one mode of presentation to the other, from

34 I stress the hypothetical character of this notion, because the writer corrected the paper tool ROM in line 15 which would strengthen the claim that the text was accomplished first. 
one aspect being specified in the drawing to another being clarified in the text, and so on. The writer is prospectively looking for the next hallmark of the ideational stratum, the reader for the gist of the argument so far undiscovered. Both are searching by shifting awareness via a specific technique of cognitive allocation.

The second working hypothesis would be that ensembles like these serve as a memorandum in keeping fragments of conceptual thinking or data for late usage, either as a trigger for scientific ideation or as a nucleus for another manuscript or both. When an author is looking at a memorandum she has produced it is probable that the writing situation as a whole is activated in memory. This means that side arms of ideation which were not put to paper take shape again, concepts omitted or discarded come back to mind..$^{35}$ Problems evaded or concealed crop up again, the aesthetics of a once reached and still tenable solution pleases. Probably the rereading writer retrieves even more autobiographical information when looking at a memorandum. This autobiographical information related to the writing situation might be, as my wording in this paragraph has suggested, emotionally tinged. Memoranda are encoded templates of mental moves of the writer. ${ }^{36}$

\section{Eighteenth Century. The Arm-Chair Companion}

At the beginning of the eighteenth century the popularizers take the stage: Desaguliers, Nollet, Sigaud de Lafond, 's Gravesande. Now a public sphere develops which is in stark contrast to the 'private' communications of the savants in the seventeenth century. This means that printed volumes take the part of the missives that were circulated before by the Transactions and by 'distribution managers' like Mersenne and later Oldenburg. Forsaking the 'one-to-one'-relationship of author and reader the printed volumes of the eighteenth century seek to establish themselves as companions and 'easy to use'-manuals for the reader. Desaguliers's preface to the "Cours de physique expérimentale" takes pains to lower the threshold for "les personnes de tous rangs de toutes les professions et même parmi les Dames": ${ }^{37}$

35 At the beginning of the twentieth century scientists like Ramón y Cajal, Henri Poincaré, Jacques Hadamard have been outspoken on the function of associations for scientific innovation. There were also some reflections on 'paper work', especially with Cajal. See Hadamard 1996; Poincaré 1921; Cajal 1940.

36 I borrow here from Howard Gruber, an experimental psychologist who turned to historiography of science. Gruber 1981,41-59. Gruber's felicitous formulation was: "a mental record of his own previous moves", 50 .

37 John Théophile Desaguliers: Cours de Physique expérimentale, traduit par L'Anglois, Tome premier, Paris, 1751. In the following: Cours. Cours, IX. 
La plus grand partie de mes Auditeurs, qui ont souhaité que je sise imprimer de Cours, étant fort peu versés dans le Mathématiques, j'ai cru qu'il était à propos d'éviter dans ma Leçons les Démonstrations géométriques trop difficiles et les Calculs algébrique, j' ai souvent prouvé la même vérité par plusieurs Expériences. ${ }^{38}$

[That is why it is necessary to, JL] employer des manières de démonstrations qui ne sont pas trop exacte, pour préparer les Auditeurs à des matières plus abstraites ${ }^{39}$.

What exactly are these "manières de démonstrations" which enable the layman reader to reconstruct in his mind the machines he saw in the lectures? Desaguliers mentions that he wants to spare the student/reader the effort of drawing the machines himself; that is why he added the copper plates to the book. Nollet and his disciple Sigaud de la Fond aim at enabling the reader to replicate the experiments being shown and described:

Le sont ces observations qui nous ont engagé à composer un Ouvrage dans lequel, mertant de dôté toutes les théories physiques, nous ne présentons à nos Lectures, que des instruments et des expériences: mais pur leur rendre eu même tems le service de ces instruments commode et familier, nous nous sommes proposés de leur indiques la manière de s'en servir, les précautions qu'il convient de prendre en quantité de circonstances, pour que le succés d l'expérience soit assuré et constant ${ }^{40}$

Nollet explicitly introduces his $L^{\prime} A r t^{41}$ as an appendix to the Leçons, ${ }^{42}$ the only purpose of the former being to hand on to the reader a manual for the instruments and machines used in the lectures. As Gerald L' E. Turner points out, Nollet actually spends much time and effort dealing with concrete problems of handling the machinery and producing coherent data. The tacit knowledge of the laboratory is made obvious and cut into pieces of comprehensible format.

In the French tradition of popularisers, which has been labelled the "French disease", ${ }^{43}$ there is an astonishing gap between this manual-style plain, matter-of-fact language and the opulent gallery of illustrations offered. The illustrations do not confront the reader with the kind of 'hermeneutic' obstacles she did encounter in the seventeenth century. There is no training in essential cognitive practices implemented in text and illustration anymore. Instead the illustrations of Nollet and Sigaud are fashioned to suit the needs of an armchair-companion who is, at best, following the demonstrations of

38 Cours, $X$.

39 Cours, XI.

40 Sigaud de la Fond: Description et usage d'un cabinet physique expérimentale par Sigaud de la Fond, seconde édition revue, corrigée et augmentée par M. Rauland, Tome premier, Paris: chez Gueffier, 1784. Préface, XI. In the following: Description.

41 Jean Antoine Nollet (Abbé): L'Art des expériences, ou avis aux amateurs de la physique, Sur le choix, la construction et l'usage des instruments; Sur la préparation et l'emploi des drogues qui servent aux expériences, nouvelle édition, Amsterdam: Chanquion, 1770.

42 Jean Antoine Nollet: Leçons de Physique expérimentale, Paris: Durand Nev., 1775. In the following: Leçons.

43 Roberts 1999, 680-714, 683. 
the Cours. In the following sections I will concentrate on the aesthetic renderings of the air pump and of optical instruments and phenomena (dark chamber, camera obscura). Of particular interest is the way, philosophical instruments are turned into thought-instruments which the reader can utilize for his mental construction. Before this I will turn to the 'mindful hand' once more.

\subsection{Maniera: Operating Hands in Illustrations (Sigaud, Desaguliers)}

The depicted hands, with all four authors they are rendered comme il faut in sleeves, become 'mindful' inasmuch as they govern the maniera of the experimenter in the arm-chair and his mental reconstruction of the machine and the experimental setting. The hands are cognitive tools which enable the reader to 'get a hold on' the material.

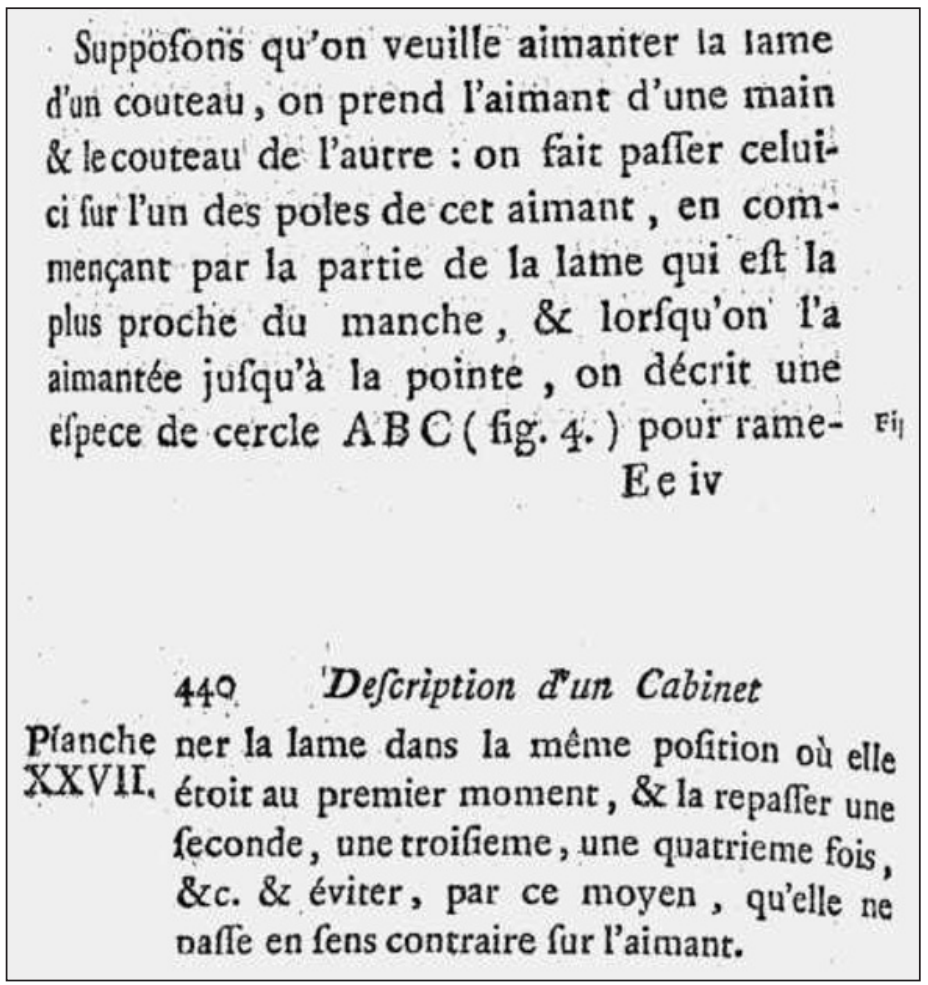

Fig. 5: Sigaud: Description, vol. 2, 439-440.

The text starts with a hint that it is a thought experiment being carried out here: "Let us suppose". The objective of the action is to magnetize the blade of a knife, which means one should avoid passing the magnetic field in two directions. This could be an everyday situation in the laboratory; one of the mechanics prepares the instruments for the experiments and magnetizes several objects. The mechanic does not necessarily need to have a thorough understanding of the natural laws or the hypotheses of the disci- 


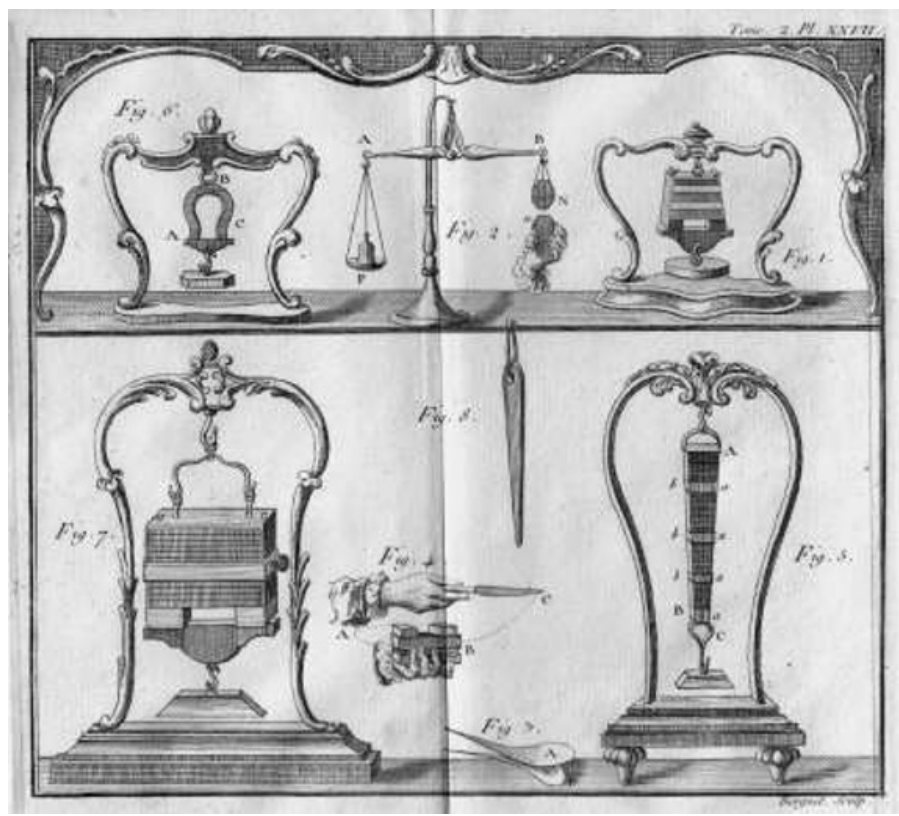

Fig. 6: Sigaud: Description, vol. 2, Plate 27.

pline regarding that phenomenon. What she needs is the enseignement of the master, to be shown the technique, doing it, having her movements supervised until they have automatized in fixed motor patterns. As with all automatized activations there are no higher cognitive, monitoring faculties involved.

The textual description of magnetizing the blade would not do this job by itself. Richard Sennett has suggested that the artisans, the musician, the surgeon, the pilot, the cook all are subject to a long apprenticeship of praxis because there is no way to teach the kinds of manual technics needed in abstracto. ${ }^{44}$ The popularizers among haute-cuisine cooks therefore developed strategies to represent the apprenticeship with the master. The description and demonstration in the cook book should be on the level of the apprentice, meaning it should display 'mistakes' or 'shortcomings' rather than full mastery. ${ }^{45}$ Second, the recipe should be embedded in a narrative or scenic frame. Finally, metaphors are allowed to make a point in the right maniera. All of these means are employed in the textbooks in question here. But knowing that you have to form a circle $\mathrm{ABC}$ does not tell you how it is shaped in

44 Sennett 2008, 119 passim.

45 Frances Willmoth has recently made an effort to build a plane table using the manual in Arthur Hopton: Speculum topographicum: Or the topographicall glasse: Of the plaine table, with a description thereof, and the parts thereunto belonging, London: Simon/Waterson, 1611. She reached at the conclusion that the manual by itself is practically of no help with the construction but that there is a plenitude of rhethorical strategies aiming at a companionship between author and reader. In: Taub 2009, 337-343, 340. 
relation to the magnet. There is no way of extracting the information needed for holding the magnet correctly if one relies solely on the text. The illustration resembles the enseignement of the master, simulates the hands-on experience of the novice in the laboratory. Contra Sennett, this is something which no text can do.

Ideally speaking, the best way of alleviating cognitive loads on the reader would be to make him/her lay hands on the book. That is precisely the phenomenon I have found in a textual witness of Desaguliers's Lectures of Experimental Philosophy (1719) in the Staatsbibliothek Berlin. In the preface of this work Desaguliers asks the reader "to correct the Faults with his pen, as the Errata direct, before he begins to read the lectures". ${ }^{46}$ Now, the book mentioned is replete with handwritten corrections of a reader who is supposedly contemporary to Desaguliers (judging from the orthographic patterns of the letters).

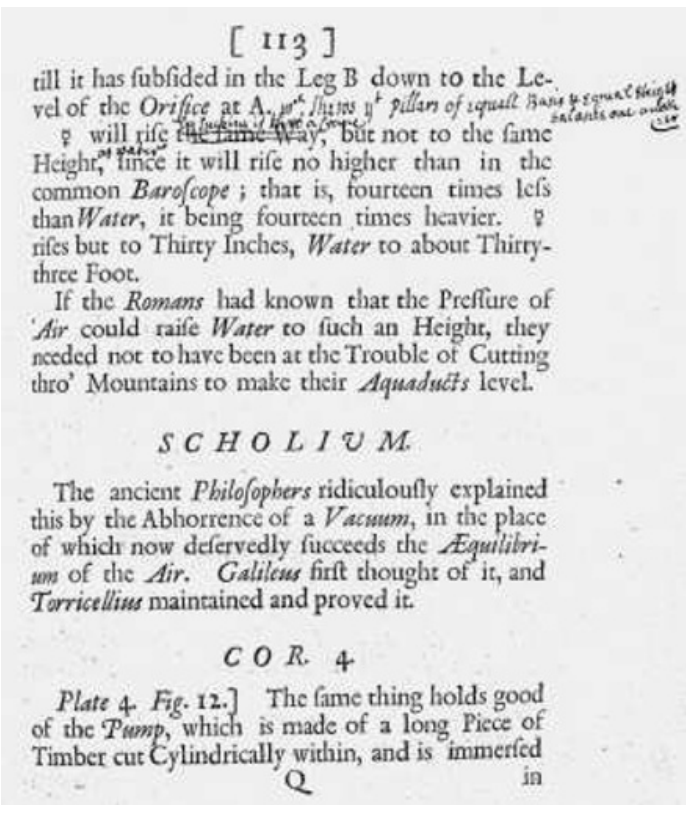

\section{[ 109$]$}

needs be that the Vapours will defeend, which by the Refiftance of the Air in their Motion, are formed into Drops of Water, from whence it cannot but Rain when the Gravity of the Air is lefiened; but when ies Gravity is increafed the Force is alfo increafed, by which it is able to fuftain the $\mathrm{V}_{2}$ pours, and that remaining the Air is clear. Hence. it is that fuch a Tube filled with $q$, and immerfed within, the Superf ficies of ftanding is is ufed to

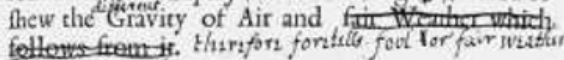
iffollowis from it

\section{Prop. XVI.}

The Elafick Force of Air inclofed in a Veflel of the fame Tenor with the ambient Air, performs as much as the Burthen of the open incumbene Air. Let there be a $T$ iwbe or a Veffel, having an open Orifice, by which there may be a Communication between the internal and external Air; if then the adjacene Parts of external Air, be lefs prefied than thofe which are within the: Yeffel, thefe will dilate themfelves by the 5 th Prop. until they come to an equal Force; but if the exeernal adjacent Parts (by the Preffure of the incum-

Fig. 7: Desaguliers: Lectures.

46 John Théophile Desaguliers: Lectures of Experimental Philosophy, wherein the Principles of Mechanicks, Hydrostatics and Opticks are demonstrated and explained at large, by a great number of curious Experiments: with a description of the air pump, and several experiments thereon: of the condensing engine ..., illustrated with several copper plates suitable to each subject, London: printed for W Mears, 1719. In the following: Lectures. Source: Staatsbibliothek Berlin, Stiftung Preußischer Kulturbesitz, Signature: Mv 2994. I would like to thank Eva Rothkirch. 
The manual corrections of the printed text resemble exactly the Errata which are displayed at the end of the book. Around page one hundred the reader quits the arduous work of deleting single words, adding endings, or altering whole sentences. Desaguliers's successful strategy is certainly not just aimed at making the book cheaper or shifting the duties of the author, the proof readers and the book seller on the reader. Desaguliers manages in this case to 'make the reader act'. 'Pen in hand', the reader scours the book in order to create a readable version of the work himself. She is forced to dedicate attention to the argument of the book, to the definitions and descriptions being altered by her. From reading she shifts to writing, thus activating a set of cognitive 'networks' and memory storages otherwise silent. ${ }^{47}$

\subsection{Traces (Nollet, Sigaud, Desaguliers)}

Gerard L'E. Turner has dealt extensively with the illustrations in Nollet's œuvre, especially L'Art and the Leçons, and has correctly stated that in L'Art "the plates [...] depart stylistically from those of the Leçons. The instruments retain all their aesthetic elegance, but they lack nearly all their decoration. Along with the wood work, the armories, the table-cloths, and the stands, people have disappeared from L'Art. The apparatuses are dismembered, and their elements can be seen clearly" ${ }^{48}$ Turner points to the fact that Nollet intended with L'Art to write a supplement to the Leçons, namely a cabinet of the instruments which had been used in the Lectures. This is in fact what Nollet adumbrates in the preface to L'Art in 1777, seven years after the last volume of the Lectures were printed. The explanation ready at hand would be that Nollet refrained from initiating cognitive practices with the reader in the description of the cabinet, that is L'Art, because here the 'cold' depiction of the instruments is what counts.

47 One anonymous reviewer has been sceptical pointing to the fact that there are many books with manual corrections of that time. This is true, but what I want to stress is a fictional/ simulative imperative on the reader to write the book/do the experiment herself. To borrow from literature, William Sterne left a blank in his 'Tristam Shandy' for the reader to fill out. Lichtenberg took efforts to make his students draw the experimental apparatus he demonstrated in his experiments. One beautiful example of this maniera of experimental cognition is a notebook by Jakob Friedrich Dyckerhoff: Collegium über Naturlehre und Astronomie bei Georg Christoph Lichtenberg, Göttingen 1796/1797. Ein Skizzenbuch der Experimentalphysik, Göttingen: Wallstein, 2011. See Loescher 2013.

48 Turner, 2002, 21. 
Nevertheless, when Sigaud de Lafond's Description et usage d'un cabinet de physique expérimentale appeared in 1784, the illustrations were replete with what Turner aptly called "theatrical hyperrealism". ${ }^{49}$ There is a rich, an opulent interieur of noble fashion, even a theatre curtain is not missing. ${ }^{50}$ The clothing seems to be utterly dysfunctional for manual work in the laboratory: the ladies who do 'research' with the microscope or are being supervised by the teacher while looking into the camera obscura seem to be in keeping with the proprieties of their class. The older girl handles the equipment diligently and with a clear research plan in mind, the younger girl exclaims at what she gains sight of in the microscope. ${ }^{51}$

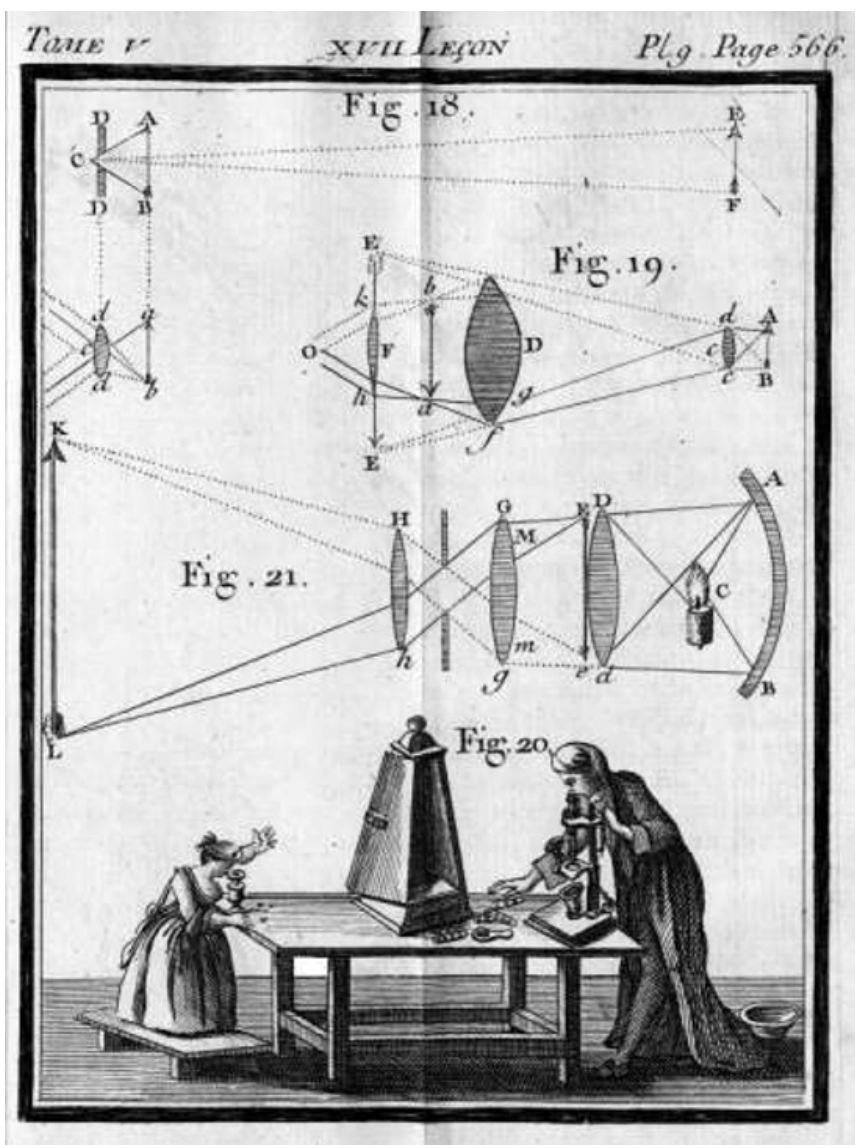

Fig. 8: Nollet: Leçons, vol. 5, 566.

49 Turner, 2002, 23.

50 Sigaud: Description, vol. 1, Pl. 9.

51 One reviewer remarked that it is not clear if the older person actually has 'a research plan in mind'. What I would like to point at is the fact that new cultural codes intrude into the experimental realm. Whereas cultural codes such as the testimony of the Gentleman helped to fix weak spots in experimental conduct in the seventeenth century, we now see a hegemony of social habitus over experimental cognition. A famous example for this phenomenon is a painting by Joseph Wright of Derby: "The Experiment with the Air Pump". See Loescher 2012, 57-81. 
Given this contrast to the British/Dutch soberness in instrument depiction as it is prevalent with Desaguliers and 's Gravesande, it seems odd at first glance that Sigaud refers to Desaguliers so often. Nollet, his teacher, is hardly granted a word. Even Desaguliers's hand is allowed to interfere with the experimental setting. ${ }^{52}$ "Theatrical hyperrealism" and the sober cabinet seem to preclude each other. But is this the case? 's Gravesande's illustrations bear remarkable features of a 'dramatization', the famous devil in the camera obscura being hardly motivated by the topic. In the chapter dealing with telescopes the reader is suddenly placed in a lovely landscape with signs of several allegorical loci. Why would 's Gravesande use these pictorial tools if otherwise he adhered to strict Newtonianism: 'picturae non fingo'? At first glance, of course, this might be an analogous strategy to the cognitive (literary) tools the first generation had used in order to make the reader the colleague - part of the experimental frame. Testifying as witness, reconstructing the experiment, sympathizing with 'failures', following the research path of the experimenter, the construction and decay of hypotheses: all this was initiated 'inside' the reader. This reader belonged to the happy few of the community.

In the eighteenth century a completely different picture evolves. Now, an anonymous 'mass-audience' needs to be addressed in a way that the symbolic capital of the community is transformed into the pecuniary capital of customers whose 'standards' of cognitive reconstruction, emotional empathy and solidification of belief differ significantly from that of the savants in the seventeenth century. These customers were not 'socialized' in the practices, they had no tacit knowledge of routines and ways of justification and - most important - while being interested in getting a foot in the new field of gaining social capital, they were by no means dependent on distinction and acceptance in this field on their own. They were free to walk out the door.

That is why the strategies of cognitive alleviation of the reader's mental 'executive' had to be changed fundamentally. First of all, baroque scenery and agents take the stage in practically all enlightenment manuals, especially in France. Instruments are pieces of art: the 'utilitarian' argument of Nollet, that lacquer and ornaments prevent the machines from corroding is, of course, just

52 «Cet appareil n'est que de pure curiosité; il réunit toutes les machines simples en une seule machine composée, et sert à démontrer que dans ce cas, l'avantage de la puissance sur la résistance est en raison composée de tous les avantages que chaque machine simple procure à la puissance. Il eût convenu, pour la plus grande exactitude, de n'employer ici qu'une seule poulie mobile, à la place des poulies moufflées $\mathrm{MN}$; mais nous n'avons rien voulu changer à la machine du D. Désaguliers, et nous l'avons décrire telle que ce célèbre Physicien l'a imaginée.» Sigaud, Description, op.cit., tome 1,279-280. The related Plate XVII in tome 1 shows a hand reaching down from the clouds interfering with the experimental setting. 
pretending: it is the aesthetic appeal of the machinery that counts. The basic finding seems to be this: the reader is 'tackled' and drawn into the landscape of tastefully arranged objects of social value by passive reception. The techniques of appealing to the reader to take part in the process of experiments becomes openly theatrical, luring, sensational. The reader is part of an aesthetic performance in the sense of prodesse et delectare: at best a passive, armchair companion to the serious natural philosopher and impresario who is performing.

As Lissa Roberts has pointed out citing David Gooding, demonstrational experiments make the instrument transparent in order to have the viewer feel as if he/she was watching nature disclosing one of her secrets. At the same time, to be sure, the grandeur of the philosopher representing mankind makes it necessary that the machine is visible: the Baconian 'imperialism' makes sense only in the presence of instruments ${ }^{53}$. On the one hand the material traces which govern the reader's cognitive processing rely on a clear-cut 'silhouette' of the depicted instrument, it is the main character in the demonstration experiment. On the other hand the depiction needs to be sufficiently vague in order to initiate the mental construction work of the reader. Too many details, too much aesthetic ornamentation obstructs the reader's cognitive effort of filling in the 'lacunae'. This "cognitive diversity" ${ }^{54}$ is an important feature of instrument descriptions and depictions in the eighteenth century.

It is not just the hands and the actors, it is the depicted instrument itself which becomes a cognitive tool. It was the German professor of physics, Georg Christoph Lichtenberg, who restored the correlation of instruments and imagination which is so dominant during Baroque 'Kircherism'. ${ }^{55}$ Lichtenberg proposed to use 'real' instruments (especially of his collection) for wide-fetched analogies to different disciplines and topics of science. Some of his 'three hundred questions to a young investigator' run:

Can I refer the object to some other object? Can I divide the object in parts? Aren't there similar things in nature? To what end does the object exist? What is it really? Is it suitable for a topic in poetry? Doesn't the object belong to a known genus of things? How does it change when the conditions change? What's happening inside of me during this ['thought experiment, JL]'? Mathematically, physically, physiologically, metaphysically, politically, morally ${ }^{56}$

53 Roberts 2007, 203-204.

54 Roberts, 2007, 204.

55 See on this topic Loescher 2012, 54-77.

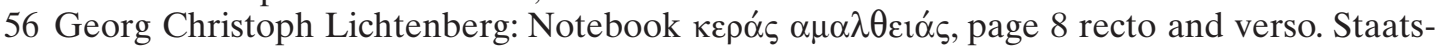
und Universitätsbibliothek Göttingen. My translation. 
"Transferring instruments" 57 are needed for this kind of analogy run wild which Lichtenberg saw already in use with Newton's inductional thinking. And this job of transferring was done, for Lichtenberg, by the real instruments in his vast collection which served as cognitive tools in projections of analogy. Ever since the 'instrumental turn' in the field of history of science took place in the early nineties (with an important 'Anti-Koyrean' account from Thomas Settle in the sixties ${ }^{58}$ ) the imaginative quality of instruments is focused.

The scientist asks not only: "I have an idea. How can I build an instrument that will confirm it?" but also: "I have a new instrument. What will it allow me to do?"59

The point to me seems to be that the cognitive function of instrument depictions and descriptions change from the seventeenth to the eighteenth century. With the savants instruments were functional - albeit precious - tools which were positioned in the centre of textual description because the instrument displayed nature. There was hardly any question as to if the instrument 'lied' or was misleading - if the objectifying stance was taken which Hooke described. ${ }^{60}$ The philosophical instrument made nature visible. In the eighteenth century the instrument is theatrically exposed on the one hand, and made transparent on the other. In demonstration experiments the instrument needs to take the stage as protagonist, but it must also give way to side characters and the space of nature. By supplying aesthetic traces and by leaving blanks the depiction transfers its object into a 'thought instrument'. These thoughtinstruments function as cognitive tools in the projection of analogy and in the cognitive 'reconstruction work' of the reader. If memoranda serve as mental records of previous moves for the writing scientist in the seventeenth century, the theatrical pathways of instrument depiction in the eighteenth century function as episodic context information aiding memory to reconstruct information.

Looking at the air pump in Sigaud's Description, it is evident that there are

57 Georg Christoph Lichtenberg: Schriften und Briefe, ed.b. Wolfgang Promies, München: Carl Hanser Verlag, 1968. Vol. 2, 545.

58 Settle 1963.

59 van Helden/Hankins 1994, 4.

60 Hevelius for instance did criticize the telescope and relied on his lynx-eyes. 


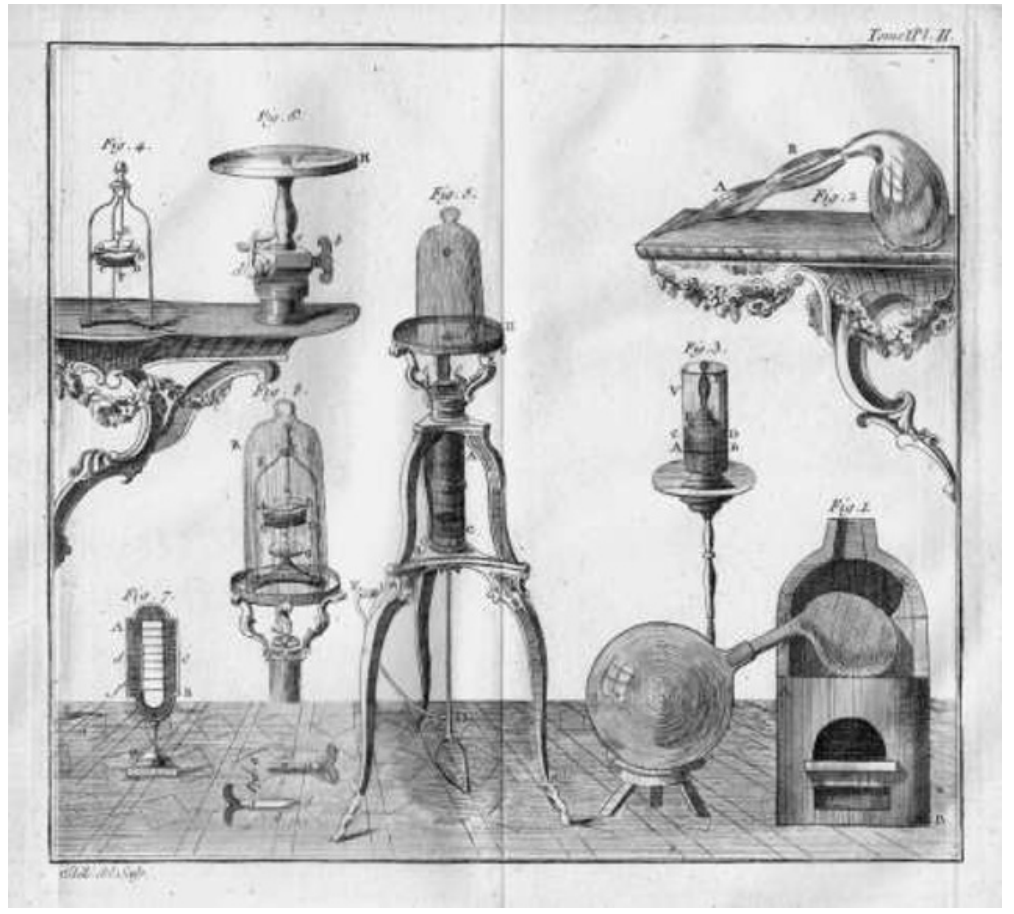

Fig. 9: Sigaud; Description, vol. 1, Pl. 2.

dominant pictorial elements which do not correlate to the machine at first glance. ${ }^{61}$ The richly ornamented tables which frame the illustration, the perspective and the 'horizontal line' - figure nr. 8 located behind this demarcation line - the admirable handicraft of the air pump itself, and finally the screws tossed on the apparently carpeted floor: these are elements guiding the reader, but they are not part of the illustration of the machine itself. The textual description on pages $30-37$ in tome 1 of the Description bears two interesting features: first there is a characteristic trait of almost all descriptions of the air pump, dating from Boyle's: the textual, therefore: 'open' reflexion on the way the machine is represented. Sometimes there are missing parts for the sake of clarity, sometimes the machine is not depicted as a whole for the same reason, sometimes parts of the machine have to be rendered transparent to make other parts be seen. ${ }^{62}$ In an interesting way the machine is both: dominant and transparent, functional and aesthetic. ${ }^{63}$

As part of the aesthetizing strategy in the eighteenth century we even

61 Just compare this depiction with the one Boyle supplied in his New Experiments (section 1 of this article).

62 «Nous avons été obligés de rendre la pompe transparente pour faire voire le piston», Description, 30.

63 This also applies for Lavoisier's impressing apparatus which is a major stake in his argument for disposing of Stahl's phlogiston. See Loescher 2014. 
Fig. 10: Desaguliers;

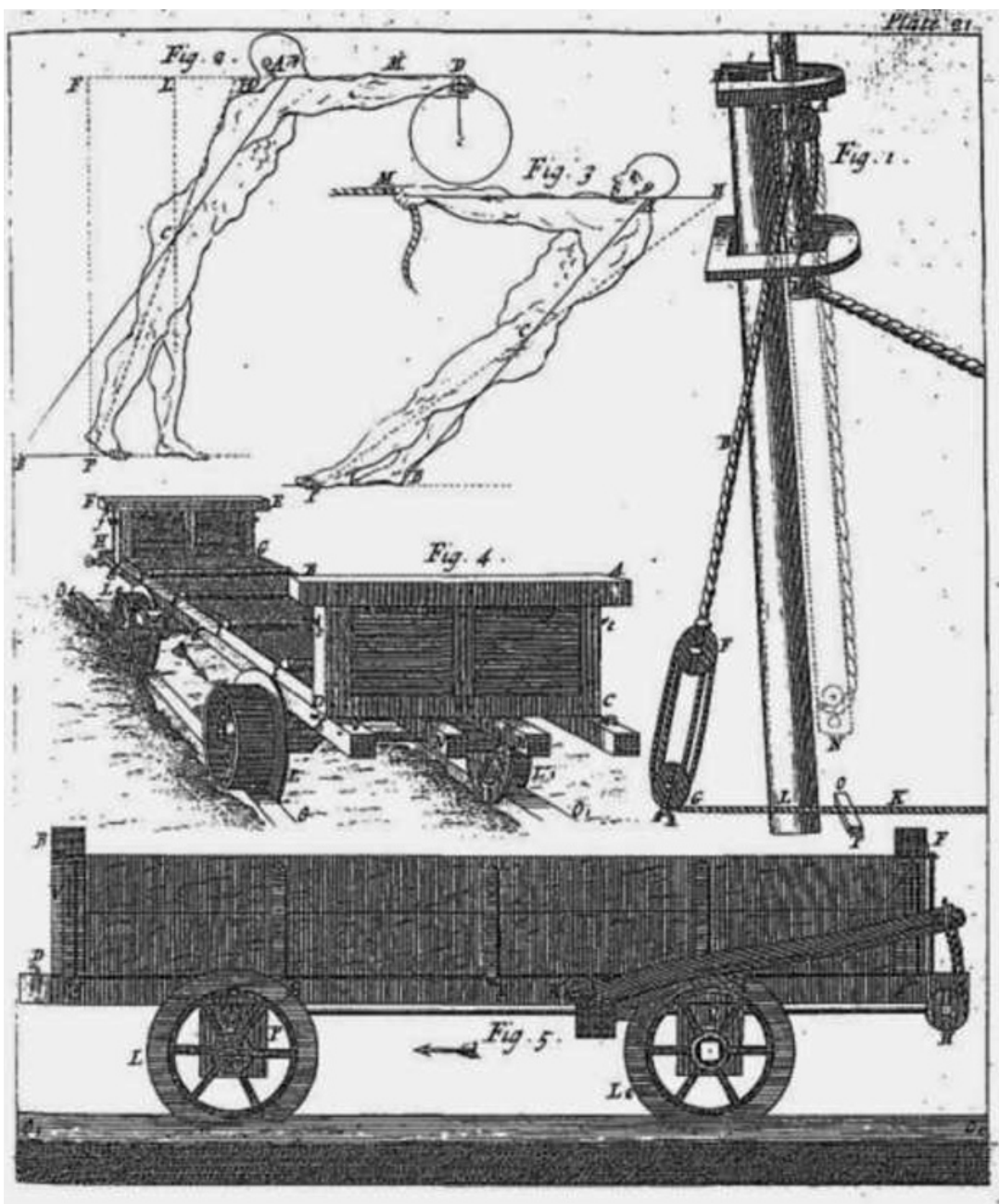

Cours, vol. 1, Pl. 21.

encounter metaphors, myths and 'miracles' which had been expelled from 'serious discourse' in the late seventeenth century. Desaguliers adheres to the classical notion of 'Greek gods' displaying the law of the lever and transmission. This is not a 'pathos of function' (of body and machine) as with Leonardo, ${ }^{64}$ but Desaguliers transposes the grandeur of old humanist education and Renaissance ideal to the industrial giants because the metaphor of godlike workers representing the law of the lever is of considerable value as a 'tracer' of episodic context memory.

4.3 Spaces ('s Gravesande, Sigaud)

64 Fehrenbach 2006, 84-109. 
Starting from the alchemic workplaces in the dark ages the laboratory is an interieur. The cabinet is situated in a room, the instruments are ordered and displayed inside, in the realm of the spacious laboratory. Hevelius's chamber for grinding lenses ${ }^{65}$ is a typical example of this: the text makes no mention of the laboratory as a whole, even the displayed instruments are mentioned rarely. The room is illuminated with 'Rembrandt-light' from a window, the floor pattern and the shading on the wall make the confines of the interior distinct. The work bench in the middle of the room carries a bunch of equipment, there is a very realistic device for rotating the plate which is installed at the ceiling and on the floor, some instruments and casting moulds are scattered on the ground. All items bear a paper tool, a letter, linking them to the descriptions in the text. What I think is important here is a kind of spatial framing of the experimental objects which helps the reader to reprocess the instruments or experiments depicted. This kind of rehearsing of thought instruments is akin to the rhetorical memorization of loci. The interior of the laboratory seems to be apt to accomplish that kind of cognitive act. There is a mnemonic ability involved which is in need of the loci of a confined room. Enumeration, ordering of items, creating 'families', that is: semantic ensembles of instruments: all of these cognitive processes are facilitated when the items are memorized with an additional 'local' memory trace. Looking at Johann Kunckels Ars vitraria experimentalis oder vollkommene GlasmacherKunst which was published in Amsterdam in 1679 at the expense of the author, ${ }^{66}$ this becomes evident.

In comparison to Hevelius's mess this is a tidy workplace with a well-orga-

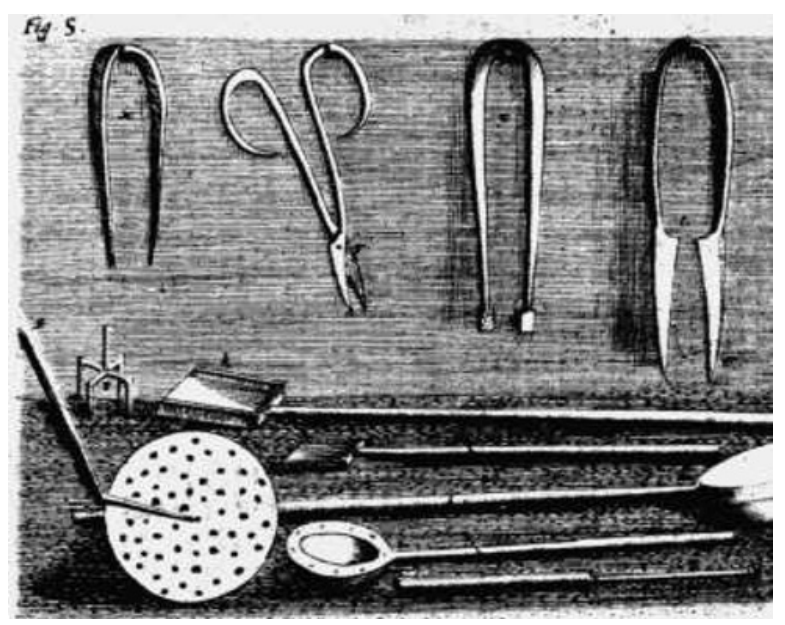

Fig. 11: Kunckel; Ars vitraria, 350.

65 Selenographia, op. cit., 6-7. See on this topic also van Helden 1996,358-396; van Helden 1994, 9-29. Hevelius's chamber depicted on 17.

66 Johann Kunckel Ars vitraria experimentalis oder vollkommene Glasmacher-Kunst, Amsterdam, Heinrich Betkio, 1679, 335. 
nized ensemble of instruments which are ordered by size and function. Again, there is a "theatrical hyperrealism", to borrow the phrase from Turner once more, in that the nails on the wall are visible, the perforated spoon is leaning to a wall not depicted. With 's Gravesande the dark chambers take an almost artistic value as they are perfect framings for the refracted light being projected on the wall. The bright-dark-contrasts and the shading bear a Rembrandt-like staging for the object. The message seems to be clear: the manipulation of nature by experiment is depicted in the seclusion of the confined space of the laboratory. Nature is outside, natural philosophy is inside.

Fig. 12: 's Gravesande: Physices, vol. 2 , Pl. $9^{67}$

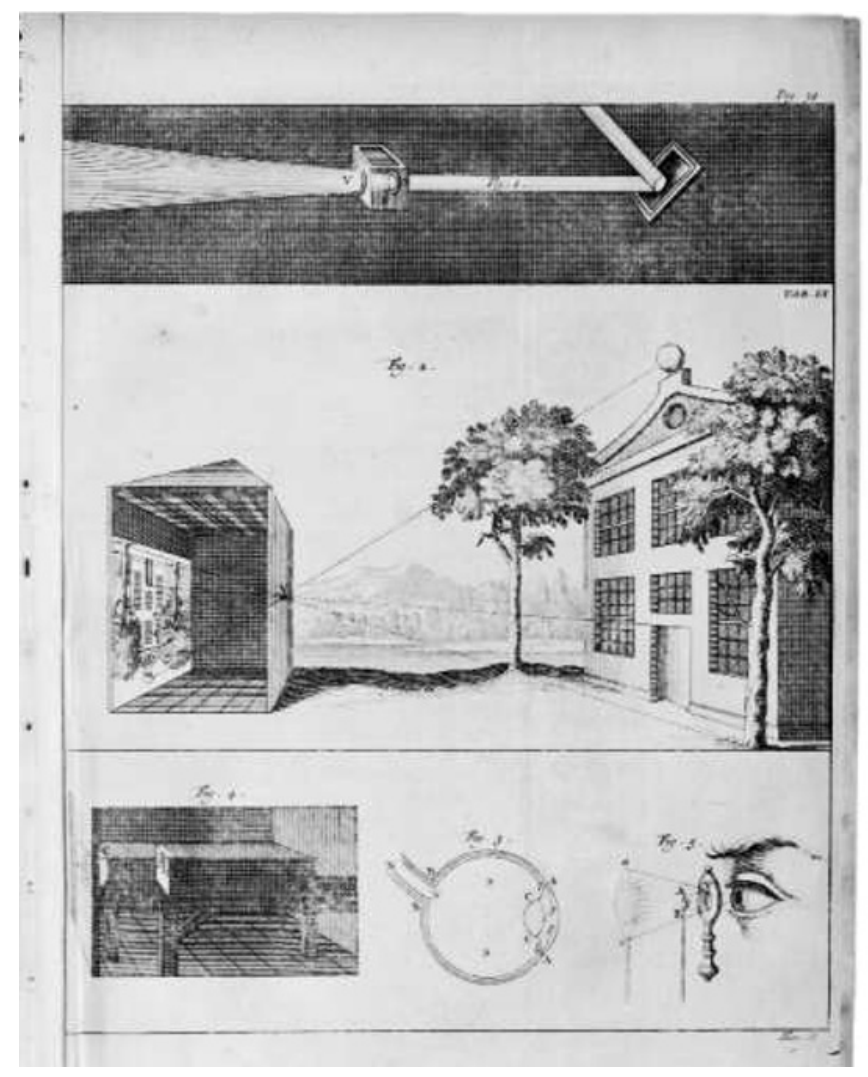

But this is only half the story. As I have mentioned before, in some respects the natural philosopher, that is the mirror character for the arm-chair-reader, is taking field trips. He is leaving the laboratory and is heading towards the 'real phenomena', as it was projected in DeLuc's, Le Sage's and Erasmus Darwin's concept of 'dissenting' natural science. In 's Gravesande: Physices, vol. 2, Pl. 9 and in Sigaud: Description, vol. 1, Pl. 8 young enthusiasts roam the landscape and perform eperiments in naturae. Somehow the instruments

67 Willem Jacob 's Gravesande: Physices elmenta mathematica, editio quarta, Leidæ, Apud Johannem Arnoldum Langerak, Johannem Et Hermannum Verbeek. Bibliop., 1748. 
are in the way when the reading disciple initiates his thought experiment of transferring analogies as Lichtenberg suggested. The instrument needs to be transformed into a cognitive tool. Instead of traces there must be space.

\section{Conclusion}

In this paper I focused on the cultural transformation of scientific practices which govern the reader's awareness and memory inscription - be it the author or the recipient, be it scientist or layman. I looked at material traces in manuscripts and on illustrations in text books. If it is true that cognitive practices like observation, economies of attention, arts of memory, and the solidification and erosion of belief are subject to cultural transformation, then the basic faculties reading and writing are, too. In a sense, this is contra to what the writing researcher would opt for: in this context cognitive faculties evolve evolutionary, that is in time windows far too encompassing to be subject to historiographical narratives. In fact, these kinds of cognitive faculties are objective in the view of the empiricist. But, again, I do not wish to struggle with these old positions taken in the field. What I am interested in is the way basic cognitive functions like reading and writing are utilized on specific historical levels in order to evoke and transform cognitive practices of the scientific self. Consequently, there is no setback in historiographical rigueur when one reaches out for the forbidden fruit of empirically informed terminology and 'thought-instruments'.

\section{Bibliography}

Bennett, Jim, "Knowing and doing in the sixteenth century: What were instruments for?" The British Journal for the History of Science 36 (2003) 129-150

Boyle, Robert, The Works (Hildesheim 1965), reprint of the first edition 1772.

Cajal, Ramón y, Reglas y consejos sobre investigacion cientifica. (Los tonicos de la voluntad). Discurso leido con ocasion de la recepcion del autor en la Real Academia de Ciencias Exactas, Fiscias y Naturales (Madrid 1940)

Carlson, W.B. \& Gorman, M.E., "A cognitive framework to understand technological creativity: Bell, Edison, and the telephone", in:Weber, R.J. \& Perkins, D.N. (Eds.), Inventive minds: Creativity in technology (Oxford 1992) 48-79

Carlson, W.B. \& Gorman, M.E., "Understanding invention as a cognitive process: The case of Thomas Edison and early motion pictures, 1888-1891", Social Studies of Science 20 (1992) 387-430

Daston, Lorraine, “On Scientific Observation”, Isis 99 (2008) 97-110

Daston, Lorraine, "Sweet Reason", Isis 75 (1984) 717-721

Daston, Lorraine, "Taking note(s)", Isis 95 (2004) 443-448 
Daston, Lorraine, "The Moral Economy of Science“, Osiris 10 (1995) 2-24

Daston, Lorraine/Peter Galison, Objectivity (New York 2007)

de la Fond, Sigaud, Description et usage d'un cabinet physique expérimentale par Sigaud de la Fond, seconde édition revue, corrigée et augmentée par M. Rauland, Tome premier, (Paris: Gueffier 1784)

Dehaene, Stanislas/Laurent Cohen/Mariano Sigman/Fabien Vinckier, "The Neural Code for Written Words: A Proposal", Trends in Cognitive Sciences 9 (2005) 335-341

Dennis, Aaron, "Graphic understanding: Instruments and Interpretation in Robert Hooke's Micrographia", Science in Context 3 (1989) 309-364

Desaguliers, John Théophile, Cours de physique expérimentale, traduit de 'Ànglois, par le R.P. Pezenas. Enrichi de Figures. Tome premier (Paris: Jacques Rollin 1751)

Desaguliers, John Théophile, Lectures of Experimental Philosophy, wherein the Principles of Mechanicks, Hydrostatics and Opticks are demonstrated and explained at large, by a great number of curious Experiments: with a description of the air pump, and several experiments thereon: of the condensing engine ..., illustrated with several copper plates suitable to each subject (London: W Mears 1719)

Drake, Stillman, Galileo at work: his scientific Biography (Chicago 1978)

Dyckerhoff, Jakob Friedrich, Collegium über Naturlehre und Astronomie bei Georg Christoph Lichtenberg Göttingen 1796/1797. Ein Skizzenbuch der Experimentalphysik (Göttingen 2011)

Fehrenbach, Frank, "Pathos der Funktion. Leonardos technische Zeichnungen", in: Helmar Schramm (Ed.): Instrumente in Kunst und Wissenschaft: zur Architektonik kultureller Grenzen im 17. Jahrhundert (Berlin 2006)

Fleck, Ludvik, Denkstile und Tatsachen: gesammelte Schriften und Zeugnisse, ed.b. Sylvia Werner (Berlin 2011)

Fleck, Ludvik, Erfahrung und Tatsache: gesammelte Aufsätze, ed.b. Lothar Schäfer (Frankfurt a. M. 1983)

Fleck, Ludvik, Entstehung und Entwicklung einer wissenschaftlichen Tatsache: Einführung in die Lehre vom Denkstil und Denkkollektiv (Frankfurt a. M. 1980)

Fueller, Carina/Jens Loescher/Peter Indefrey, "Writing superiority in cued recall", Frontiers in Psychology 4 (2013): http://www.frontiersin.org/cognitive_science/ 10.3389/fpsyg.2013.00764/abstract

Galilei, Galileo, Notes on motion, Digital Edition Ms Gal. 72, Folios 33 bis 196. Biblioteca Nazionale Centrale, Florence; Istituto e Museo di Storia della Scienza, Florence; Max Planck Institut für Wissenschaftsgeschichte Berlin: http://www. mpiwg-berlin.mpg.de/Galileo_Prototype/INDEX.HTM

Gooding, David, "What is Experimental about Thought Experiments?" Proceedings of the Biennal Meeting of the Philosophy of Science Association 2 (1992) 280-290

Gruber, Howard, "On the Relation of Aha-Experiences and the construction of ideas", History of Science 19 (1981) 41-59

's Gravesande, Willem Jacob, Physices elmenta mathematica, editio quarta (Leiden Johannes Arnoldus Langerak 1748)

Hacking, Ian, "Do we see through a microscope?" in: Paul M. Churchland/Clifford Hooker (eds), Images of Science. Esssays on Realism and Empiricism (Chicago 1985) 99-117

Hacking, Ian, "Experimentation and Scientific Realism”, in: J. Ceplin (Ed.): Scientific 
Realism (Berkeley 1984) 155-172

Hacking, Ian, Representing and Intervening (Cambridge 1983)

Hadamard, Jacques, The Mathematician's Mind. The Psychology of Invention in the Mathematical Field (Princeton 1996)

Hoffmann, Christoph, Unter Beobachtung. Naturforschung in der Zeit der Sinnesapparate (Göttingen 2006)

Holmes, Frederic Lawrence, "Argument and narrative in scientific writing", in: Peter Dear (ed.): The Literary Structure of Scientific Argument: Historical Studies (Philadelphia 1989) 164-181

Holmes, Frederic Lawrence, "Laboratory Notebooks: Can the Daily Record Illuminate the Broader Picture?" Proceedings of the American Philosophical Society 134 (1990) 349-366

Holmes, Frederic Lawrence, "Scientific writing and scientific discovery”, Isis 78 (1987) 220-235

Holmes, Frederic Lawrence, “The Fine Structure of Scientific Creativity”, History of Science 19 (1981) 60-70

Holmes, Frederic Lawrence, Lavoisier and the Chemistry of Life. An Exploration of Scientific Creativity (Madison 1985)

Hooke, Robert, 'Micrographia' or Some Physiological Descriptions of Minute Bodies made by Magnifying Glasses with Observations and Inquiries thereupon (London: Martyn/Allestry 1665)

Hutchins, Edwin, Cognition in the wild (Cambridge 1995)

Klein, Ursula, "Paper tools in Experimental Cultures", Studies in History and Philosophy of Science 32 (2001) 265-302

Krauthausen, Karin/Omar Nasim (Eds.), Notieren, Skizzieren: Schreiben und Zeichnen als Verfahren des Entwurfs (Zürich 2010)

Kunckel, Johann, Ars vitraria experimentalis oder vollkommene Glasmacher-Kunst" (Amsterdam: Heinrich Betkio 1679)

L'E. Turner, Gerard, "Teaching by Demonstration. The Development of Popular Science, Science Teaching, and its Apparatus in Eighteenth-Century Europe", in: Lewis Pyenson/Jean-Francois Gauvin (eds.), The Art of Teaching Physics. The Eighteenth Century Demonstration Apparatus of Jean Antoine Nollet (Sillery 2002) 110

Loescher, Jens (ed.), Writing as a cognitive tool. Researach across disciplines, GFL 2/3 (2009): http://www.gfl-journal.de/Issue_2_2009.php

Loescher, Jens, "Lichtenbergs Gedankeninstrumente", Oxford German Studies 41 (2012) 57-81

Loescher, Jens, "Produktives Notat. Jakob Friedrich Dyckerhoffs Mitschriften von Lichtenbergs Vorlesungen", Editionen in der Kritik, 27 (2013)

Loescher, Jens, Schreiben. Literarische und naturwissenschaftliche Innovation bei Goethe, Lichtenberg, Jean Paul (Berlin 2014)

Nersessian, Nancy, "Opening the black box: cognitive science and history of science", Osiris 10 (1995) 194-211

Nersessian, Nancy, "Reasoning from Imagery and Analogy in Scientific Concept Formation", Proceedings of the Biennial Meeting of the Philosophy of Science Association 1 (1988) 41-47

Nollet, Jean Antoine (Abbé), L'Art des expériences, ou avis auy amateurs de la 
physique, Sur le choix, la construction et l'usage des instruments; Sur la préparation et l'emploi des drogues qui servent aux expériences, nouvelle edition (Amsterdam: Chanquion 1770)

Nollet, Jean Antoine, Leçons de Physique expérimentale (Paris: Durand Nev. 1775)

Poincaré, Henri, The Value of Science (Leipzig 1921)

Rheinberger, Hans-Jörg, Experiment, Differenz, Schrift: zur Geschichte epistemischer Dinge (Marburg an der Lahn 1992)

Rheinberger, Hans-Jörg, Experimentalsysteme und epistemische Dinge: eine Geschichte der Proteinsynthese im Reagenzglas (Göttingen 2001)

Roberts, Lissa, "Mapping the engines and skill in eighteenth-century Holland", in: Lissa Roberts/Simon Schaffer/Peter Dear (eds.), The Mindful Hand: Inquiry and Invention from the Late Renaissance to Early Industrialization (Amsterdam 2007) 197-220

Roberts, Lissa, "Science becomes electric. Dutch interaction with the electrical machine during the eighteenth century", Isis 90 (1999) 680-714

Roberts, Lissa/Simon Schaffer/Peter Dear (Eds.), The Mindful Hand: Inquiry and Invention from the Late Renaissance to Early Industrialization, (Amsterdam 2007)

Sennett, Richard, The Craftsman (New Haven 2008)

Settle, Thomas: “An experiment in the history of science”, Science 133 (1963) 19-23

Source: Staatsbibliothek Berlin, Stiftung Preußischer Kulturbesitz, Signature: Mv 2994

Taub, Liba (ed.), On scientific instruments, Studies in History and Philosophy of Science 402009.

Tomasello, Michael, Die kulturelle Entwicklung des menschlichen Denkens (Franfurt a. M. 2000)

Tweeny, Ryan D. \& David Gooding (Eds.), Michael Farraday's Chemical Notes, Hints, Suggestions and Objects of Pursuit of 1822 (London 1991)

van Helden, Albert, "Galileo and Scheiner on Sunspots: a Case Study in the visual Language of Astronomy", Proceedings of the American Philosophical Society 140 (1996) 358-396

van Helden, Albert, “The birth of the scientific instrument, 1550-1700”, in: John Burke (ed.), The uses of Science in the age of Newton (Berkeley 1983) 49-84

van Helden, Albert/Thomas L. Hankins (ed.): Instruments in the History of Science, Osiris 9 (1994).

van Helden, Albert/Thomas L. Hankin, "Introduction: Instruments in the History of Science", in: Albert van Helden/Thomas L Hankins (eds.), Instruments in the History of Science, Osiris 9 (1994) 1-7

van Helden, Albert, "Telescopes and Authority from Galileo to Cassini", in: Albert van Helden/Thomas L Hankins (eds.), Instruments in the History of Science, Osiris 9 (1994) 8-29

van Leeuwenhoek, Antoni, The Collected Letters of Antoni van Leeuwenhoek (Amsterdam 1939)

Vertesi, Janet, "Instrumental images: the visual rhetoric of self-presentation in Hevelius's Machina Coelestis" The British Journal for the History of Science 43 (2010) 209-243

Warner, Deborah Jean, "What is a scientific instrument, when did it become one, and why?" The British Journal for the History of Science 23 (1990) 83-93 